\title{
Hydrometeorological Consequences on the Water Balance in the Ganga River System Under Changing Climatic Conditions using Land Surface Model
}

\section{Mohd Sayeed UI Hasan}

Aliah University https://orcid.org/0000-0002-5388-3383

Abhishek Kumar Rai ( $\square$ abhishek@coral.iitkgp.ac.in )

Aliah University https://orcid.org/0000-0002-4082-0359

\section{Research Article}

Keywords: GLDAS, GIS, Drought, Groundwater Level, M-K Test, Water Budget

Posted Date: November 9th, 2021

DOI: https://doi.org/10.21203/rs.3.rs-1045395/v1

License: (c) (i) This work is licensed under a Creative Commons Attribution 4.0 International License.

Read Full License

Version of Record: A version of this preprint was published at Journal of King Saud University - Science on May 4th, 2022. See the published version at https://doi.org/10.1016/j.jksus.2022.102065. 


\title{
Hydrometeorological Consequences on the Water Balance in the Ganga
}

\section{River System Under Changing Climatic Conditions using Land Surface}

\section{Model}

\author{
Mohd Sayeed UI Hasan ${ }^{1,2}$, Abhishek Kumar Rai ${ }^{1^{*}}$ \\ ${ }^{1}$ Centre for Oceans, Rivers, Atmosphere and Land Sciences, Indian Institute of Technology Kharagpur, \\ West Bengal, India-721302 \\ ${ }^{2}$ Department of Civil Engineering, Aliah University, New Town, West Bengal, India-700160 \\ *Corresponding Author: abhishek@coral.iitkgp.ac.in
}

\section{Abstract}

United Nations Sustainable Development Goal (SDG) ensures adequately accessible water and management for all. Due to the rapid increase in population and industries along the Ganga river, it is necessary to estimate the water budget for fulfilling the demand for water in the future. The M-K test conducted on the Noah-Land Surface Model data for 72 years results in maximum declining trend of water budget in the Yamuna Lower $(\mathrm{Q}=-3.82 \mathrm{BCM} / \mathrm{year})$, and minimum in the Damodar sub-basin $(\mathrm{Q}=-0.10 \mathrm{BCM} / \mathrm{year})$. All the sub-basins show increase in groundwater level (mbgl) except the Kali Sindh, which shows decreasing trend $(\mathrm{Q}=-0.07$ $\mathrm{m} /$ year). The extreme severe groundwater drought were estimated using Standard Groundwater Level Index (SGWLI), of the values for the Ram Ganga Confluence (SGWLI=2.44;2005), Upper stream of Gomti (SGWLI=2.06;2014), Ghaghra (SGWLI=2.22;2005), Ram Ganga $(\mathrm{SGWLI}=2.28 ; 2005), \quad$ Yamuna $\quad$ Lower $\quad($ SGWLI=2.13;2007), Kali $\quad$ Sindh (SGWLI=2.30,2.67;2002,2003), Chambal Upper $\quad$ (SGWLI=2.30,2.20;2001,2003), Son (SGWLI=2.02;2010), Gandak (SGWLI=2.37;2010),Kosi (SGWLI=2.08;2012), Damodar (SGWLI=2.72;2010), and Bhagirathi (SGWLI=2.06;2014) were obtained for a period of 1996 to 2016 using a total of 62,050 observed well data. The obtained in-situ point data are converted 
into the surface raster using geostatistical technique. Our results show declining trend in the water budget of all the 19 sub-basin of the Ganga basin, and also the groundwater drought in several parts. Policy makers will benefit from our findings as they can use them to further UN Sustainable Development Goals such as ending poverty (SDG-1), hunger eradication (SDG2), clean water \& sanitation (SDG-6), socioeconomic development (SDG-8) and climate action (SDG-13) all of which must be accomplished before 2030.

Keywords: GLDAS, GIS, Drought, Groundwater Level, M-K Test, Water Budget

\section{Introduction}

United Nation Sustainable Development Goal ensures accessibility and sustainable water and sanitation for all. It also highlights the importance of growing concern on water and sanitation problems in the global political agenda (SDG,2018). As per the Fourth Assessment Report by the Intergovernmental Panel on Climate Change (IPCC), the average worldwide temperatures could increase by $1.1-6.4^{\circ} \mathrm{C}$ by the end of the 21 st century (IPCC, 2007). Climate change may influence the worldwide and regional hydrological cycle, varying the spatial and temporal distribution of major elements of the hydrological-cycle such as rainfall, runoff, evaporation, and soil moisture, causing re-distribution of surface and groundwater resources over a spatiotemporal scales, and enhancing the possibility of a number of hydrological extremes (Qin et al., 2011). Changing precipitation or melting snow and ice in many areas changes hydrological processes and impacts water supplies in terms of quantity and quality (Jarraud and Steiner, 2012). The rate of precipitation is not evenly distributed over the global spatial extent. The distribution of open fresh water on Earth's surface available in reservoirs, rivers, and swamps are $87 \%, 2 \%$ and $11 \%$, respectively (Gleick,1993). Computations of the water storage was frequently done by applying: in-situ observations, hydrological modelling and remote sensing (Hall et al., 2011;Duan and Bastiaanssen, 2013). Unavailability of ground-based gauge stations, especially in developing and underdeveloped countries, and uncertainty in the hydrological model leads to foster the use of remote sensing data for sustainable water resource management ( Fang et al., 2008; Singh et al., 2016;Bring et al., 2017 ). Assessing water storage and stream discharge will permit us to comprehend the dynamics of the topographical division of the global water cycle, and to predict the significances of alteration on water resources (Zhang et al., 2006). 
The studies of groundwater depletion reveales that maximum depletion rate was found in IndoGangetic plains of northern India, consequently Bangladesh, also the region of Nepal and Pakistan (Aeschbach-Hertig \& Gleeson,2012). Rodell et al., (2009) use the GRACE data, and Soil moisture dataset variation integrating with hydrological modelling shows that groundwater depletion takes place at an average rate of $4.0 \pm 1.0 \mathrm{~cm} /$ year in terms of equivalent water height over the region of Haryana (Delhi), Punjab and Rajasthan. The results show that the rate of depletion will be cause severe problems in the near future leading to water scarcity in several areas. Therefore, there is an urgent need for estimating the water budget for an efficient and sustainable management of water resources. A water budget defines the amount of water change retained in an environment, such as a basin, sub-basin or watershed, is balanced by the amount at which water flow takes place in and out of the region (Healy et al.,2007).

Water available in the Earth's system is constant, although certain variations may occur locally depending on geologic conditions and the regional climate (Birylo et al., 2018). Observed variations in an area's water supply can be used over time to determine the impacts of climate changes and human activity on water supplies (Healy et al., 2007). Apart from securing drinking water sources of groundwater, water budgets can be utilised for a number of applications such as land use/cover planning, water use developments, landfill location approvals, recharge well locations, residential and industrial water supply, irrigation water supply, metropolitan water supplies, total extraction, dam construction, and stormwater management (Maliva and Missimer, 2012).

Global Land Data Assimilation System (GLDAS) model used by various researchers globally for the computation of water budget in different regions (Matrai,2011;Birylo 2017; Roads et al. 2003; Seneviratne et al. 2004; Swenson and Wahr,2002). Globally many researchers deploy the non-parametric Mann-Kendall (MK) test for the trend analysis of hydroclimatic variable for understanding the long term effect over the region due to climate change (Bocheva et al.,2009; Kysley,2009; Petrow and Merz,2009; Korhonen and Kouusisto, 2010, Dinpashoh et al. 2011; Blöschl et al. 2012).

In this paper, we first estimate the water budget in the study area, secondly, time series analysis using a non-parametric test of the hydroclimatic variables is conducted which helps in understanding the trends. Finally, groundwater drought locations are identified using the insitu data from the monitoring wells. All these analyses were done into all the 19 sub-basin of the Ganga basin, since most of the Indian population lives along the Ganga river which has highly fertile agricultural land. . We apply a non-parametric test which helps to delineate the sub-basin which is more prone to water scarcity over the long time series analysis. 
89 Water budgets is a component used by the decision maker to estimate the hydrologic process for the sustainable development of water resource management.Results of analysis may be useful forthe government and policymakers who apply the basin level water management plans to achieve various objectives.

\section{Study Area}

The river Ganga originates from the Gangotri glacier in the district of Uttarkashi, Uttarakhand of the Himalayas regionat an elevation of $\sim 7010 \mathrm{~m}$. With the Tropic of Cancer running across it, the Gaga basin is situated between $21^{\circ} 6^{\prime}$ and $31^{\circ} 21^{\prime}$ North Latitudes and $73^{\circ} 02^{\prime}$ and $89^{\circ} 05^{\prime}$ East Longitudes and having an area of $\sim 0.88$ million $\mathrm{Km}^{2}$. Ganga basin is bounded by the Himalayas in the north, Vindhaya and Chota Nagpur plateau in the south, Indus and Aravali in the west and meeting the confluence of Brahmaputra and Bay of Bengal in the east. Therefore, the Ganga river system has a large spatial variation in terms of ecological and hydrometeorological perspectives. Due to changing climate conditions, the Himalayan glaciers are vulnerable to extinction or retreat which is an alarming condition for maintaining a sustainable the flow of water into the river system and its tributaries. The effect of temporaland spatial variability of temperature, precipitation and evapotranspiration may significantly impact the water balance into the Ganga river system. The Ganga drains through a basin of extraordinary variation in geology, geomorphology, altitude, climate, land use, vegetation, and cropping pattern. India comprises $\sim 22$ major basins, out of which the Ganga basin plays a crucial role in economic development. The Yamuna Lower sub-basin (15.45\%) has the largest per cent drainage area of the Ganga basin. 


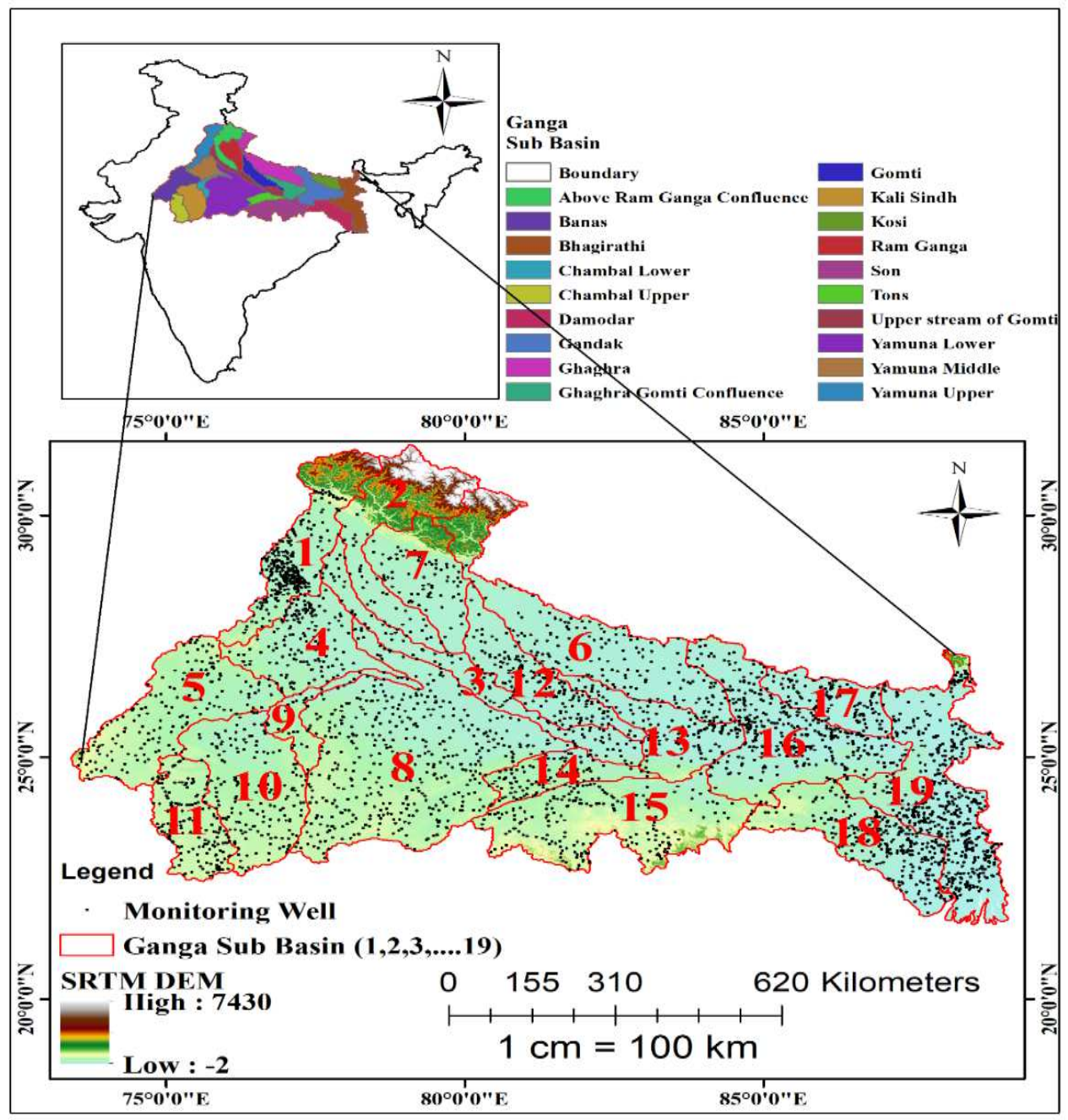

Fig.1 Geovisualization of the spatial location of Ganga basin

\section{Data Source and Methodology}

The first and foremost thing in the monitoring and estimation of the water budget is to delineate the river basin. Published map from CWC and ISRO was imported in the GIS platform, then georeferenced the map using Geographic Coordinate System having datum WGS 1984 maintaining the spatial extent of the boundary (CWC and ISRO,2012). All the 19 sub-basin are digitised for the extraction of spatial data for further analysis. The development of GLDAS was done by the teams from different organisations like National Aeronautics and Space Administration (NASA), Goddard Space Flight Centre (GSFC) and National Oceanic and Atmospheric Administration (NOAA), and National Centres for Environmental Prediction 
(NCEP) based on the long term data by using prediction and simulation models. Deployment of ground and space-borne observation the two constrained applied for land surface states include employing Land Surface Models (LSM) including meteorological data and, another by data assimilation techniques (Rodell et al., 2004). With the development of technology and research, four GLDAS Land Surface Model (LSM) were developed (Fang et al., 2008). The two main GLDAS land surface models include Mosaic (Seller et al.,1986), NOAH (Chen et al.,1996; Betts et al.,1997), whereas the other two including Community Land Model (CLM, Dai et al.,2003), Variable Infiltration Capacity model (VIC, Liang et al.,1994). Based on the hydrological flux from inward and outward, completing the water budget component in the study area using vertical (Precipitation and Evapotranspiration) and horizontal (Runoff) flux within the basin. GLDAS-2 NOAH land surface model having 36 parameters including 3hourly and monthly data product from 1948 to till now. The NOAH LSM are classified into five categories including past $3 \mathrm{hr}$ time average (tavg=12 parameter), past 3-hr accumulated (Qcc=3 variable), instantaneous (inst=14 variable), forcing past 3-hr average (f_tavg=3 variable), and forcing instantaneous (f_inst=4 variable)(Spennemann et al., 2015).

The GLDAS having the two-component for the long term climatological data studies are GLDAS-2.0 (Rodell et al., 2004) from 1948 to 2010 using global meteorological forcing data set from Princeton University (Sheffield et al.,2006), on the other hand, GLDAS-2.1 (Rodell et al.,2004) having the dataset from 2000 to till now by incorporating with a combination of Global Data Analysis System (GDAS), AGRicultural METeorological (AGRMET) modelling system radiation data, and disaggregated Global Precipitation Climatology Project (GPCP).

The GLDAS NOAH land surface model L4 dataset, which uses as for the estimation of the water budget from 1948 to 2019 having a spatial resolution of $0.25 * 0.25$ degrees with monthly time average temporal data downloaded from Giovanni (https://giovanni.gsfc.nasa.gov/giovanni/). GLDAS_NOAH025_ M_2.0 (Beaudoing et al., 2019) data used for water budget from 1948 to 1999, and from 2000 to 2019 GLDAS_NOAH025_M_2.1 (Beaudoing et al., 2020) dataset are used.

Monitoring water availability in the study area, the water flow in river/stream depends upon the following component in the basin contributing to the flow are total precipitation rate (Rainf_f_tavg), evapotranspiration (evaporation and transpiration, Evap_tavg), rate of infiltration in the soil, surface water such as soil moisture, reservoirs, lake, and in addition groundwater storage and the last one is storm surface runoff (Qs_acc), this component provides complete water budget. The precipitation is an important component added into the earth 
system in the form of an inflow and leaving system by means of evapotranspiration and streamflow within the catchment.

The objective of this paper is to estimate the water budget (balance) by using various satellite sensors and spectral measurements, which can be used for deriving water budget components.

\subsection{Computation of Water Budget}

The hydrological cycle considering the terrestrial water storage are given below (Peixoto and Oort, 1992; Yeh et al.,1998; Oki, 1999; Seneviratne et al. 2004);

$$
\operatorname{Pr}=\mathrm{ET}+\Delta \mathrm{S}+\mathrm{Qs}+\mathrm{Qb}
$$

Where Pr denotes precipitation, ET is Evapotranspiration, $\Delta \mathrm{S}$ shows Change in water storage, Qs is surface runoff, and Qb represents sub-surface runoff (Base Flow) within the system.

Within a given geographic region, most hydrological basin groundwater runoff is considered to be discharged into streams and, hence, is measured along with surface water runoff (Rasmusson,1968; Seneviratne et al. 2004)). Therefore, for large study area the equation 1 can be modified into equation 2, based on the studies carried out globally (Syed et al., 2005; Sheffield et al., 2009; Gao et al., 2010; Sahoo et al., 2011; Pan et al.,2012; Long et al.,2015; Lv et al. 2017; Birylo et al. 2018a; Birylo et al., 2018b) assuming there is no lateral flow of groundwater along the river basin in the study area (Wan et al., 2015). Considering that there is no surface, sub-surface, or groundwater net inflow/outflow in the study area, surface runoff and base-flow contribute to discharge. The first-order equation for surface water budget is given below:

$$
\Delta S=\overline{\left(\frac{d S}{d t}\right)}=\overline{\operatorname{Pr}}-\overline{E T}-\overline{Q s}
$$

$\mathrm{Pr}=\mathrm{SF}+\mathrm{RF}$

Where $\mathrm{dS} / \mathrm{dt}$ denote the water budget $\left(\mathrm{kg} / \mathrm{m}^{2} / \mathrm{s}\right)$ in the study area over the time " $\mathrm{t}$ ", Pr is forcing time average variable for total precipitation rate $\left(\mathrm{kg} / \mathrm{m}^{2} / \mathrm{s}\right)$ including snowfall (SF) and rainfall (RF), ET time average variable for evapotranspiration $\left(\mathrm{kg} / \mathrm{m}^{2} / \mathrm{s}\right)$, Qs is the accumulated storm surface runoff $\left(\mathrm{kg} / \mathrm{m}^{2} / \mathrm{s}\right)$, over bar denotes the temporal average water budget and its component, mean in the study area. 
Precipitation is the source and sinks that surface receives from which evapotranspiration is lost to the atmosphere. Evapotranspiration is the cumulative amount of water vaporises into the atmosphere, including evaporation from land surfaces and transpiration from vegetation and plants. Runoff is the horizontal flow of water from the basin depending upon the morphometric characteristics of the terrain. It is important to note here that the GLDAS model, is a column model, and lateral flow is not included, so this equation is valid in the sense that runoff and subsurface runoff actually is no net-input in the river basin, its really going through the eventually goes through the river stream of discharge, so that is one of the assumptions in deriving this. Another important thing is that when we look at these parameters GLDAS like system, there is no irrigation or other management such as reservoir or dam management are included, so this is an all-natural hydrologic cycle that we are looking at. To obtain the water budget component, we can use a number of data sources such as precipitation from GPM IMERG, and GLDAS download from Giovanni, for evapotranspiration ALEXI, MOD 16, and GLDAS download from SERVIR Global and Giovanni, and runoff which cannot be provided directly from satellite but estimated by GLDAS which is also downloaded from Giovanni, provide all these data for computing water budget. We used GLDAS because all parameters have the same spatial and temporal resolution. Therefore, the biggest advantage of GLDAS is that everything is uniformly gridded in pace and time, which gives better accuracy than using different satellite sensors of different temporal resolution.

\subsection{Non-Parametric Test for Time Series and Trend Detection For Hydrometeorological}

\section{Paratemets}

The non-parametric test employs to evaluate the magnitude and trend of the hydroclimatic parameter (Bisht et al., 2018; da Silva et al., 2015; Panda and Sahu, 2019). The time-series data are equally spaced and arranged in ascending order from 1948 to 2019.

\subsubsection{Measurement of the Significance of the Trend}

The detection of trends is a difficult task because of the various characteristics of the data. The main goal of trend analysis is to determine whether the values of the data are increasing, decreasing, or remaining static over time (Kisi and Ay 2014; Marques et al., 2015)). In order to detect trends, nonparametric tests Mann-Kendall $S$ Statistic is computed as follows(Mann,1945; Kendall,1975;Mohsin and Gough, 2010)) using Eq. 4 and 5 
223 Where $\mathrm{Tj}$ and $\mathrm{Ti}$ are the annual values in year $\mathrm{j}$ and $\mathrm{i}, \mathrm{j}>\mathrm{i}$, respectively.

224 The variance is computed as:

$$
\operatorname{Var}(S)=\frac{\left(n(n-1)(2 n+5)-\sum_{i}^{P} t_{i}\left(t_{i}-1\right)\left(2 t_{i}+5\right)\right)}{18}
$$

226 Where $\mathrm{n}$ is the number of data points, $\mathrm{P}$ is the number of tied groups; $\mathrm{t}$ is the number of data values in the Pth group.

A tied group is a collection of data samples that all have the same value (i.e. they are all tied). When the sample size is greater than or equal to 30 , the standard normal test statistic Zs is derived from equation 7 :

231

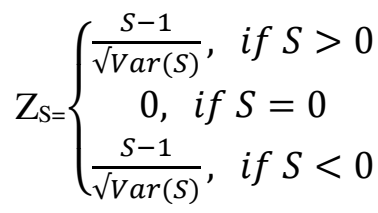

232

$$
T_{i}=\frac{x_{j}-x_{k}}{j-k} \text { for } \mathrm{i}=1,2, \ldots, \mathrm{N},
$$

\subsubsection{Estimation of the magnitude of the trend Using Sen's Slope Estimator}

Sen's slope deals with the estimation of the magnitude of the trend based on the time series data arranged in order of sequence within a time frame $($ Sen,1968) using equation 8.

Where $T_{i}, x_{j}$ and $x_{k}$ represents the magnitude of trend and the time series data at time $j$ and $k$ $(\mathrm{J}>\mathrm{k})$, correspondingly. 
The median of Sen's slope $\left(\mathrm{Q}_{\mathrm{med}}\right)$ estimator is calculated from the number of time periods $(\mathrm{N})$ derived from the magnitude of the trend $\left(\mathrm{T}_{\mathrm{i}}\right)$ from smallest to largest. The $\mathrm{Q}_{\text {med }}$ is computed as $T_{[(N+1) / 2]}$ for $\mathrm{N}$ as odd, similarly $\frac{T_{[N / 2]}+T_{[(N+2) / 2]}}{2}$ for $\mathrm{N}$ as even.

The values of $\mathrm{Q}_{\text {med }}$ helps to find the nature of the trend of hydroclimatic parameters. The positive values show the increasing trend, whereas negative values depict the declining trend of the variable based on the steepness of the slope.

\subsection{Standard Groundwater Level Index (SGWLI) for Groundwater Drought Analysis}

The groundwater drought is a situation where groundwater sources fail as a direct consequence of drought (Calow et al.,1999; Bloomfield and Marchant, 2013). Groundwater drought is a particular type of hydrological drought that occurs when groundwater recharge, heads or discharge deviate from normal, which leads to the consequences of groundwater supply to maintain the eco-hydrological process. The observed groundwater level data was collected from the Central Groundwater Board for the year 21 years from 1996 to 2016, having a total number of sample points 62,050 based on pre-monsoon, monsoon, post-monsoon (rabi), and post-monsoon (Kharif). The average annual groundwater level was prepared using the point data converted into the raster surface using the geostatistical technique of inverse distance weighted method (Watson,1992;Hasan and Rai, 2020). The statistical values of the sub-basin were computed using zonal statistics on the GIS platform. Based on the water level index, the groundwater drought, , which is used to analyse the spatial and temporal stress of groundwater is defined as (Bhuiyan, 2000; Tallaksen and van Lanen 2004; Shahid \& Kumar, 2010; Halder et al., 2020) Eq. 9.

$$
S G W L I=\frac{G W L_{i, j}-\overline{G W L_{j}}}{\sigma_{j}}
$$

Where $G W L_{i, j}$ i represents year ranging from 1996-2016 having groundwater level of $j^{\text {th }}$ subbasin; $\overline{G W L_{J}}$ and $\sigma_{j}$, shows long term mean and standard deviation of the particular year having $\mathrm{j}^{\text {th }}$ sub- basin respectively. The classification of groundwater drought was done into five classes, based on the estimated values of standard groundwater level index (SGWLI) as extreme severe drought $>2.00$, severe drought $>1.50$, moderate drought $>1.00$, mild drought $>0.00$, and no drought $<0.0$ (Bhuiyan, 2000). 


\section{Results and Discussion}

The assessment of dynamic groundwater resources in India has been carried out by the Central Ground Water Board (CGWB) and the concerned State Government authorities (CGWB, 2012). The dynamic groundwater resources are also known as annual replenishable groundwater because it is replenished/recharged each year. According to the latest assessment, the annual replenishable groundwater resource in this region was estimated at 431 billion cubic meters (BCM) as in March 2009, of which 396 BCM is considered available for exploitation for various uses after retaining $35 \mathrm{BCM}$ for natural release during the non-monsoon time for the maintenance of environmental flows in springs, streams and rivers (CGWB, 2012). The stage of groundwater development in India for the years 2004,2009 and 2011 was obtained as $58 \%, 61 \%$, and $62 \%$, respectively (Kulkarni et al., 2018). The assessment water availability per person for the years 2001 and 2011 was $1813 \mathrm{~m}^{3}$ and $1545 \mathrm{~m}^{3}$ respectively, having the projected demand reduced to $1340 \mathrm{~m}^{3}$ and $1140 \mathrm{~m}^{3}$ for the year 2025 and 2050 (DoWR-GOI,2019). The accuracy of NOAH land surface model for the Ganga basin shows Nash Sutcliffe Efficiency (NSE) more than 0.8 (Prakash Kushwaha et al., 2021).

1. Yamuna Upper: The Yamuna Upper sub-basin is located between $27^{\circ} 18^{\prime}$ to $31^{\circ} 25^{\prime}$ north latitudes and $75^{\circ} 45^{\prime}$ to $78^{\circ} 37^{\prime}$ east longitudes in India. Most of the river's discharge is accounted for by the physiographic and geological characteristics of the Yamuna Upper sub-basin, which is located in the Himalayan range. On average, this area gets approximately $1500 \mathrm{~mm}$ of rain each year. The Ganga basin's Yamuna Upper sub-basin has a total catchment of 35,798 square kilometres. Uttarakhand, Delhi, Himachal Pradesh, Uttar Pradesh, Haryana, and Rajasthan are all part of the sub-basin. The hydrometeorological analysis of long term data using the M-K test shows the significant $(\mathrm{P}<0.05)$ trend of increasing GWL $(\mathrm{mbgl})$ at $0.29 \mathrm{~m} /$ year and decreasing trend of temperature at $-0.01 \mathrm{oC} / \mathrm{year}$. The insignificant trend $(\mathrm{P}>0.05)$ of precipitation, evapotranspiration, surface runoff, and water budget having trend magnitude of -1.12 $\mathrm{mm} /$ year, $-0.21 \mathrm{~mm} /$ year, $0.08 \mathrm{~mm} /$ year, and $-0.45 \mathrm{BCM} / \mathrm{year}$, respectively in the Yamuna 

maximum 1.36 for the year 1998 and 2014, respectively. The results shows only moderate drought takes place in this region from 2013,2014,2015, and 2016, having SGWLI values 1.05,1.36,1.35, and 1.19 respectively (Fig.9).

2. Above Ram Ganga Confluence: The Above Ramganga Confluence sub-basin is located between $27^{\circ} 12^{\prime}$ to $31^{\circ} 28^{\prime}$ north latitudes and $77^{\circ} 47^{\prime}$ to $80^{\circ} 15^{\prime}$ east longitudes

3. Upper stream of Gomti: The geographical area of the Upstream of Gomti confluence to Muzaffarnagar sub-basin is between $24^{\circ} 52^{\prime}$ to $29^{\circ} 37^{\prime}$ north latitudes and $77^{\circ} 35^{\prime}$ to $83^{\circ} 12^{\prime}$ east longitudes of the nation. This is the upstream section of the Gomti River, 
which has a catchment of 29061 square kilometres. The sub-basin is entirely within the state of Uttar Pradesh. Trend analysis using the M-K test along with Sen's slope was done to evaluate the nature of hydrometeorological parameters. The results show the significant $(\mathrm{P}<0.05)$ increase in trend of evapotranspiration, runoff, and GWL as $0.99 \mathrm{~mm} /$ year, $0.19 \mathrm{~mm} /$ year, $0.12 \mathrm{~m} /$ year, and decreasing trend of water budget 0.68BCM/year, respectively. Precipitation shows an insignificant decreasing trend of $0.26 \mathrm{~mm} /$ year.In the year 2014 , it is observed that the extreme severe groundwater drought takes place (SGWLI=2.06), severe drought in 2014, and moderate drought in the year 2015 (SGWLI=1.09). Eight different year shows mild drought, and rest of the other year falls under no groundwater drought condition.

4. Yamuna Middle: The Yamuna Middle sub-basin is located between $26^{\circ} 15^{\prime}$ to $28^{\circ} 43^{\prime}$ north latitudes and $75^{\circ} 51^{\prime}$ to $79^{\circ} 19^{\prime}$ east longitudes in India. The Yamuna is the main river that flows through this sub-basin. The entire catchment of the Yamuna Middle sub-basin of the Ganga basin is 34,586 square kilometres. The states of Delhi, Haryana, Rajasthan, and Uttar Pradesh are all included in the sub-basin. Utangan or Banganga, Gambhir, Bangan, Kasaundi, Jhirha Karwan and Nadi, are some of the other important rivers in this sub-basin. The $\mathrm{M}-\mathrm{K}$ test results show the significant $(\mathrm{P}<0.05)$ increasing trend of evapotranspiration $(\mathrm{Q}=0.69 \mathrm{~mm} /$ year $)$, temperature $(\mathrm{Q}=0.01$ oC/year $), \mathrm{GWL}$ $(0.30 \mathrm{~m} /$ year $)$, and decreasing trend of water budget $(\mathrm{Q}=-0.05 \mathrm{BCM} / \mathrm{year})$. The insignificant trend of precipitation having Sen's slope of -0.08 (Fig.7 \& 8). The severe groundwater drought takes place in the year 2016 (SGWLI=1.70), moderate groundwater drought also takes place in the year 2007,2009,2010,2014,2015 having SGWLI values greater than unity but less than 1.5. For the year 


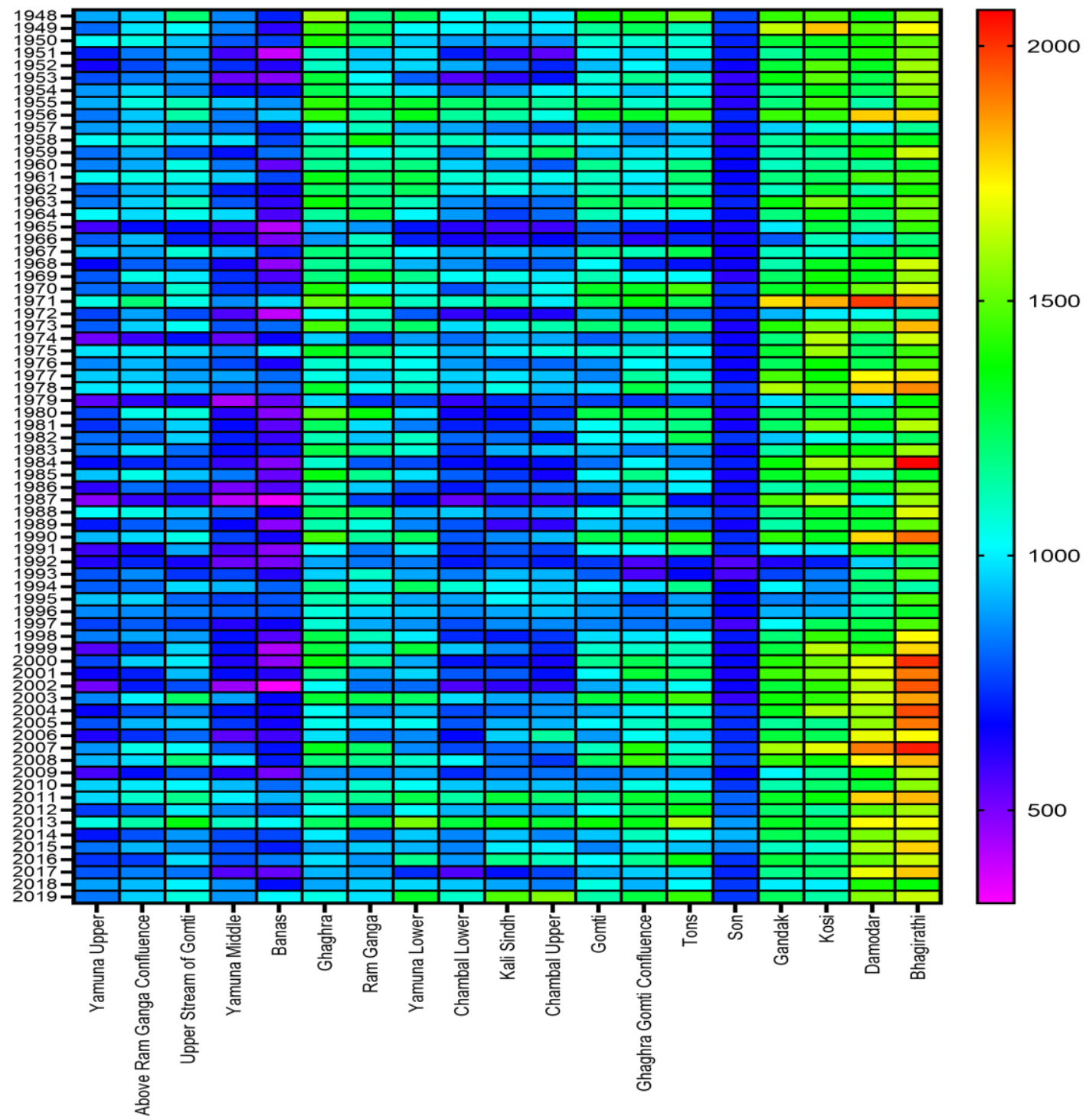

Fig.2 Temporal distribution of precipitation from 1948-2019 in sub-basin (mm/year)

5. Banas: The Banas sub-basin is positioned between the latitudes $27^{\circ} 34^{\prime}$ north and $24^{\circ}$ $15^{\prime}$ the longitudes of $73^{\circ} 24^{\prime}$ and $76^{\circ} 57^{\prime}$ east of in the nation. The Banas is the major river, with the Morel, Berach, and Gambhir as tributaries flowing into the Banas subbasin. The Ganga basin's Banas sub-basin has a total catchment of 51651 square kilometres. It flows into the states of Rajasthan and Madhya Pradesh in portions. The hydrometeorological effects on the sub-basin of Ganga sub-basin using MK-test shows 
the significant increasing $(\mathrm{P}<0.05)$ trend of $\operatorname{runoff}(\mathrm{Q}=0.12 \mathrm{~mm} /$ year $)$, temperature $(0.02$ oC/year), and groundwater level $(0.17 \mathrm{~m} /$ year $)$. No significant trend was observed for precipitation (0.69 mm/year) and water budget (-0.11 BCM/year). Banas sub-basin drought condition (Fig.9).

6. Ghaghara: The Ghaghara sub-basin is located between the latitudes of $25^{\circ} 47^{\prime}$ to $30^{\circ}$ shows moderate groundwater drought for the consequitive three years 2008,2009,2010, other eight years are under mild drought, and rest of the years having no groundwater $31^{\prime}$ north and the longitudes of $79^{\circ} 29^{\prime}$ to $84^{\circ} 49^{\prime}$ east in the nation. The Ghaghara and the Sarda rivers, as well as the Rapti and the Little Gandak, are some of the important tributaries that run through this sub-basin. The Ghaghara river begins nearby Manasarovar Lake, at the height of 4,800 meters. In Nepal, the river is also recognised as Manchu and Karnali. The river moves in Nepal after flowing for 72 kilometres in a south-easterly direction. Ghaghara moves in India at Kotia Ghat nearby Royal Bardia National Park in Nepal Ganj. Further, it flows for approximately 25 kilometres as the river Girwa. The Ghaghara river's entire catchment is 1,27,950 square kilometres, with 45 per cent of it falling in India. The Ganga basin's Ghaghara sub-basin has a total catchment of 58,634 square kilometres. The Sarda River is a major tributary of the Ghaghara River, which forms a portion of the border between India and Nepal. Other significant tributaries of the Ghaghara river are the Sarju, Rapti, and Little Gandak. The Ghaghara river is 1,080 kilometres long before it meets the Ganga river (near Doriganj, downstream of Chhapra town in Bihar). It flows across portions of Uttar Pradesh, Uttarakhand, and Bihar. The significant $(\mathrm{P}<0.05)$ long term climatic effect was observed in the Ghaghra sub-basin using the MK-test shows the increasing trend of GWL $(\mathrm{Q}=0.08 \mathrm{~m} /$ year $)$, whereas the decreasing trend of precipitation $(\mathrm{Q}=-$ 

was observed for evapotranspiration $(\mathrm{Q}=0.51 \mathrm{~mm} / \mathrm{year}$, runoff $(\mathrm{Q}=0.12 \mathrm{~mm} /$ year $)$, and temperature. Ghaghra shows the extreme severe groundwater drought for the year 2005 (SGWLI=2.21), 2006,2010,2011,2012 shows the moderate drought, and rest of the other years having no groundwater drought (Fig.9).

7. Ram Ganga: The Ramganga sub-basin is located between the latitudes of $27^{\circ} 7^{\prime}$ to $30^{\circ}$ $6^{\prime}$ north and the longitudes of $78^{\circ} 14^{\prime}$ to $80^{\circ} 8^{\prime}$ east in India. The Ramganga is the Ganga's first significant tributary. It climbs to approximately 3,110 meters in the lower Himalayas near the Lohba village in Uttarakhand's Garhwal district. The Ramganga river is 596 kilometres long from its source to its confluence with the Ganga. The river runs through hilly terrain and includes a lot of falls and rapids along the way. The river joins the plains at Kalagarh, near the Garhwal district's boundary, where the renowned (Fig.9). 
8. Yamuna Lower: The Yamuna Lower sub-basin is located between $22^{\circ} 51^{\prime}$ to $28^{\circ} 1^{\prime}$ north latitudes and $77^{\circ} 6^{\prime}$ to $81^{\circ} 55^{\prime}$ east longitudes in India. In the Yamuna lower subbasin, the Sind, Dhasan, Betwa, and Ken rivers are the main tributaries. With a total catchment area of 1,24,867 square kilometres, the Yamuna Lower sub-basin is the biggest sub-basin in the Ganga basin. The Uttar Pradesh and Madhya Pradesh make up the majority of the sub-basin. The hydrometeorological analysis of long term data using the $\mathrm{M}-\mathrm{K}$ test shows the significant $(\mathrm{P}<0.05)$ trend of the increasing trend of evapotranspiration $(\mathrm{Q}=0.78 \mathrm{~mm} /$ year $), \quad$ runoff $\quad(0.45 \mathrm{~mm} / \mathrm{year}), \quad$ temperature $\left(0.01^{\circ} \mathrm{C} /\right.$ year $)$, whereas decreasing trend of water budget $(\mathrm{Q}=-3.82 \mathrm{BCM} / \mathrm{year})$. The insignificant trend $(\mathrm{P}>0.05)$ of precipitation $(\mathrm{Q}=-0.9 \mathrm{~mm} / \mathrm{year})$ and $\mathrm{GWL}(\mathrm{Q}=0.07$ $\mathrm{m} /$ year). Yamuna Lower shows the etreme as well as severe groundwater drought condition for the consequitive year of 2007 and 2008, having SGWLI value of 2.13 and 1.64 respectively. This sub-basin also shows the moderate,mild and no groundwater drought condition (Fig.9).

9. Chambal Lower: The Chambal Lower sub-basin is located between the latitudes of $24^{\circ} 43^{\prime}$ to $26^{\circ} 55^{\prime}$ north and the longitudes of $76^{\circ} 38^{\prime}$ to $79^{\circ} 17^{\prime}$ east in the nation. In the Chambal Lower sub-basin, the Yamuna meets its tributary river, the Chambal. The Ganga basin's Chambal Lower sub-basin has a total catchment of 10,941 square kilometres. The Madhya Pradesh state, as well as portions of Rajasthan and Uttar Pradesh, are drained by the sub-basin. The annual trend analysis of 72 years using the M-K test reveals that the significant increasing trend $(\mathrm{P}<0.05)$ of evapotranspiration $(\mathrm{Q}=0.55 \mathrm{~mm} /$ year $)$ and temperature $(\mathrm{Q}=0.02 \mathrm{oC} /$ year, whereas decreasing trend of water budget $(\mathrm{Q}=-0.28 \mathrm{BCM} / \mathrm{year})$. There is an insignificant trend observed in Chambal 
Lower of precipitation $(-1.07 \mathrm{~mm} /$ year $)$, runoff $(\mathrm{Q}=0.06 \mathrm{~mm} /$ year $)$, and $\mathrm{GWL}$ $(0.01 \mathrm{~m} /$ year). Chambal lower shows moderate groundwater drought for the year 2002,2003, and 2007 having SGWLI>1, while rest of the seven years shows mild drought, and eleven different years shows no groundwater drought condition (Fig.9).

10. Kali Sindh: The Kali Sindh and Others up to Confluence with Parbati sub-basin are situated in Pakistan between $22^{\circ} 33^{\prime}$ to $26^{\circ} 3^{\prime}$ north latitudes and $75^{\circ} 15^{\prime}$ to $77^{\circ} 23^{\prime}$ east longitudes. The main rivers in this sub-basin are the Kali Sindh and Parbati, which converge at the Banas River, a feeder of the Yamuna. The sub-basin of the Ganga basin has a catchment of 48492 square kilometres. It runs through the states of Madhya Pradesh and Rajasthan. Trend analysis using the M-K test along with Sen's slope done to evaluate the nature of hydrometeorological parameters, shows a significant increasing $(\mathrm{P}<0.05)$ trend of runoff $(\mathrm{Q}=0.7 \mathrm{~mm} / \mathrm{year})$, and temperature $(\mathrm{Q}=0.02 \mathrm{oC} /$ year $)$, whereas insignificant trend $(\mathrm{P}>0.05)$ of precipitation $(\mathrm{Q}=0.22 \mathrm{~mm} /$ year $), \quad$ evapotranspiration $\quad(\mathrm{Q}=0.42 \mathrm{~mm} /$ year $)$, water budget $(\mathrm{Q}=-$ 0.47BCM/year), and GWL (Q=-0.07). Kali Sindh shows the two extreme severe groundwater drought for the year 2002, and 2003 having SGWLI of 2.29, and 2.67 respectively. Moderate groundwater drought found in the year 2004 and 2005, another different years shows mild and no drought condition (Fig.9).

11. Chambal Upper: The Chambal Upper sub-basin is located between the latitudes of $22^{\circ} 25^{\prime}$ to $25^{\circ} 5^{\prime}$ north and the longitudes of $74^{\circ} 49^{\prime}$ to $76^{\circ} 12^{\prime}$ east in the nation. The Chambal is the main river in the lower sub-basin of the Yamuna. The Ganga basin's Chambal Upper sub-basin has a total catchment of 25,546 square kilometres. The subbasin drains typically in the states of Madhya Pradesh and Rajasthan. The Sipra or 
Kshipra river, Chamla river, Gangi Nadi, and Retam Nadi, to mention a few, all drain into this sub-basin. Yashvant Sagar (Corporation) Dam, Rana Pratap Sagar Dam, and other important dams are located in this sub-basin. The hydrometeorological parameters of Kali Sindh and Chambal Upper show a similar trend, but the magnitude of Sen's slope different as a significant increase $(\mathrm{P}<0.05)$ in runoff $(\mathrm{Q}=0.92 \mathrm{~mm} / \mathrm{year})$, and temperature $(\mathrm{Q}=0.01 \mathrm{oC} / \mathrm{year})$, whereas insignificant $(\mathrm{P}>0.05)$ trend was observed in precipitation $(\mathrm{Q}=-0.02 \mathrm{~mm} /$ year $)$, evapotranspiration $(\mathrm{Q}=-0.01 \mathrm{~mm} /$ year $)$, water budget $(\mathrm{Q}=-0.2 \mathrm{BCM} /$ year $)$, and $\mathrm{GWL}(\mathrm{Q}=0.02 \mathrm{~m} /$ year $)$. Chamal Upper also correspond to two different extreme severe groundwater drought for the 2001 and 2003, and severe drought in the year 2002 (SGWLI=1.67). Rest of different years hows mild as well as no drought condition (Fig.9).

12. Gomti: The Gomti sub-basin is located between the latitudes of $25^{\circ} 25^{\prime}$ to $28^{\circ} 40^{\prime}$ north and the longitudes of $79^{\circ} 59^{\prime}$ to $83^{\circ} 14^{\prime}$ east in the nation. The Gomti river begins at Mainkot, about 3 kilometres east of Pilibhit, Uttar Pradesh, at the height of 200 meters, and flows for around 940 kilometres. Between the Ramganga and Ghaghara systems, the river drains the region. The Ganga basin's Gomti sub-basin has a total catchment of 29,865 square kilometres. The sub-basin is entirely within the state of Uttar Pradesh. Before merging with the Ganga at Audihar, Jaunpur, the river runs through Shahjehanpur, Lucknow, Kheri, Barabanki, Faizabad, Sultanpur, Varanasi, Jaunpur, and Ghazipur districts. Lucknow, Uttar Pradesh's capital, is located on the banks of the Gomti River. The Gachai, the Jomkai, the Sai, the Barna, the Saryu, the Chuha, the Kalyani, the Giri, and the Kathna are just a few of the important rivers that run through this sub-basin. The significant $(\mathrm{P}<0.05)$ long term climatic effect was observed in the Gomti sub-basin using MK-test shows an increasing trend of GWL $(\mathrm{Q}=0.09 \mathrm{~m} / \mathrm{year})$ 
and decreasing trend of water budget $(\mathrm{Q}=-1.09 \mathrm{BCM} / \mathrm{year})$. Results also shows that there was no significant trend $(\mathrm{P}>0.05)$ found in precipitation $(\mathrm{Q}=-1.29 \mathrm{~mm} / \mathrm{year})$, evapotranspiration $(\mathrm{Q}=0.18 \mathrm{~mm} /$ year $)$, runoff $(\mathrm{Q}=0.18 \mathrm{~mm} / \mathrm{year})$, and temperature $\left(0.01^{\circ} \mathrm{C} /\right.$ year $)$. Gomti shows the severe drought for the year 2014, and 2016, and moderate, mild and drought condition for different year (Fig.9).

13. Ghaghara and Gomti Convergence: The Ghaghara and Gomti Convergence subbasin are located in the nation between $24^{\circ} 34^{\prime}$ to $26^{\circ} 48^{\prime}$ north latitudes $81^{\circ} 34^{\prime}$ to $84^{\circ}$ 47' east longitudes and. The Gomti and Ghaghara rivers flow into the main Ganga river in this sub-basin. The Banas Nadi, the Durgauti Nadi, the Chhoti Sarju, the Gomati, the Karamnasa, the Kao Nadi, and the Majhoi are just a few of the rivers that flow through this sub-basin. The Ganga basin's Ghaghara sub-basin has a total catchment of 26,254 square kilometres. It flows into the states of Bihar and Uttar Pradesh. The significant $(\mathrm{P}<0.05)$ long term climatic effect was observed in Ghaghra sub-basin using MK-test shows the increasing trend of evapotranspiration $(\mathrm{Q}=1.44 \mathrm{~mm} / \mathrm{year})$, runoff $(\mathrm{Q}=0.34 \mathrm{~mm} /$ year $), \mathrm{GWL}(\mathrm{Q}=0.06 \mathrm{~m} /$ year $)$, and decreasing trend of water budget $(\mathrm{Q}=-$ 0.62BCM/year). The insignificant trend was observed in the Ghaghra Gomti Confluence shows that precipitation $(\mathrm{Q}=0.73 \mathrm{~mm} / \mathrm{year})$ and temperature $(\mathrm{Q}=0.01$ ${ }^{\circ} \mathrm{C} /$ year). This sub-basin only shows the moderate,mild and no groundwater drought condition (Fig.9). The minimum and maximum SGWLI value ranges from -1.77 to 1.43 .

14. Tons: The Tons sub-basin is located between the latitudes of $23^{\circ} 58^{\prime}$ and $25^{\circ} 17^{\prime}$ north and the longitudes of $80^{\circ} 18^{\prime}$ and $83^{\circ} 20^{\prime}$ east in the nation. The Tons, the main river in this sub-basin, is the Yamuna's longest tributary. It runs across Garhwal, Uttarakhand's 
Himalayan westernmost region. The river rises at 3,900 meters above sea level and meets the Yamuna below Kalsi. It is the Yamuna's largest tributary, with its source on the 6,315-meter-high Banderpoonch Mountain. Tons carry more water than the Yamuna. It drains mostly across Madhya Pradesh and portions of Uttar Pradesh, with a total catchment of 16,905 square kilometres. The Satna and Belan rivers, in addition also shows moderate, mild and no groundwater drought condition (fig.9).

15. Son: The Sone sub-basin is located between the latitudes of $22^{\circ} 40^{\prime}$ to $25^{\circ} 42^{\prime}$ north and the longitudes of $80^{\circ} 6^{\prime}$ to $85^{\circ} 4^{\prime}$ east in the nation. The Sone, the principal river in this sub-basin, is an important Ganga right bank tributary. The river begins at the height of 600 meters in Sonbhadra, Madhya Pradesh, in the Maikala range of mountains. The basin's entire catchment is 65,110 square kilometres. The Sone and Mahanadi rivers, the Rihand, the Kanhar, the Banas, the Gopat, the Ghaghar, and the North Koel are all significant tributaries of the Sone River. The river's entire length is 784 kilometres, with approximately 82 kilometres in Uttar Pradesh, 500 kilometres in Madhya Pradesh, and the rest 202 kilometres in Bihar. The river flows into the Ganga approximately 16 kilometres upstream of Dinapur in Bihar's Patna district. The states of Uttar Pradesh, Bihar, Jharkhand, Chhattisgarh, Madhya Pradesh and make up the sub-basin. The significant $(\mathrm{P}<0.05)$ long term climatic effect was observed in the Son sub-basin using 
MK-test shows an increasing trend of evapotranspiration $(\mathrm{Q}=1.26 \mathrm{~mm} / \mathrm{year})$, runoff $(\mathrm{Q}=0.37 \mathrm{~mm} /$ year $), \mathrm{GWL}(\mathrm{Q}=0.07 \mathrm{~m} /$ year $)$. Precipitation and temperature show the insignificant trend in the Son sub-basin of the Ganga river system. For the year 2010, Son sub-basin shows the extreme severe groundwater drought having SGWLI value of 2.02. It also shows severe, moderate, mild and no groundwater drought condition.

16. Gandak and others: The Gandak and others sub-basin are located in the nation between $24^{\circ} 0^{\prime}$ to $27^{\circ} 23^{\prime}$ north latitudes and $83^{\circ} 41^{\prime}$ to $87^{\circ} 44^{\prime}$ east longitudes and. The Gandak and Punpun rivers, as well as the Baya, Mohana, Dhadhar, Sakri, Harohar, Kiul, Badua, Painiar, Phalgu, Dardhu, Dardha, and Morhar, are some of the important

17. Kosi: The Kosi sub-basin is located between $25^{\circ} 25^{\prime}$ to $26^{\circ} 48^{\prime}$ north latitudes and $85^{\circ}$ to $87^{\circ} 21^{\prime}$ east longitudes of the nation. The Kosi is a significant branch of the Ganga River, which originates in the Himalayas at an altitude of 7,000 meters. The Kosi River has a total drainage area of 74,500 square kilometres, of which is 11,000 square kilometres in India. Nepal and Tibet account for almost $80 \%$ of Kosi's catchment area. 
Approximately 77 per cent of the land is cultivated. The Kosi basin has a total catchment of 95,156 square kilometres, including 18,413 square kilometres in India. The Bagmati, the Balan, the Kareha, the Lakhandal, and the Kamla, are some of the important rivers flowing in this sub-basin, in addition to the main river, the Kosi and the Adhwara. The sub-basin is entirely within the state of Bihar. Because of the regular floods of the Kosi River, the river is also known as the 'Sorrow of Bihar'. The M-K test for the Kosi sub-basin shows the remarkable significant $(\mathrm{P}<0.05)$ trend of the increasing severe drought condition (Fig.9).

18. Damodar: The Damodar sub-basin is located between the latitudes of $21^{\circ} 44^{\prime}$ to $24^{\circ}$ $25^{\prime}$ north and the longitudes of $84^{\circ} 35^{\prime}$ to $88^{\circ} 20^{\prime}$ east in India. The Ganga basin's Damodar sub-basin has a total catchment of 41965 square kilometres. The Damodar is the major river, with the Usri, Barakar, and Kasai as tributaries flowing into the Damodar sub-basin. Jharkhand and West Bengal are the states where it flows. The hydro-meteorological effects on the Damodar sub-basin of Ganga using MK-test shows the significant increasing $(\mathrm{P}<0.05)$ trend of precipitation $(\mathrm{Q}=4.37 \mathrm{~mm} / \mathrm{year})$, evapotranspiration $(\mathrm{Q}=2.68 \mathrm{~mm} /$ year $), \quad \operatorname{runoff}(0.81 \mathrm{~mm} / \mathrm{year})$, temperature $\left(0.01^{\circ} \mathrm{C} /\right.$ year $), \mathrm{GWL}(0.07 \mathrm{~m} /$ year $)$, whereas insignificant $(\mathrm{P}>0.05)$ trend of water budget (-0.1 BCM/year). Damodar sub-basin shows the wide range of SGWLI from 1.36 to 2.72 , having all the aspect of groundwater drought as well as no drought condition. 

sub-basin is located in the nation between $21^{\circ} 39^{\prime}$ to $26^{\circ} 56^{\prime}$ north latitudes and $86^{\circ} 7^{\prime}$ to $89^{\circ} 28^{\prime}$ east longitudes. The main Ganga empties into the Bay of Bengal via this subbasin. The Hoogly, the Jamuna, the Gumani, the Balason, the Dwarka, the Mayurakshi, the Bhagirathi, and the Mahananda are only a few of the drains in the sub-basin. The Ganga basin's sub-basin has a total catchment of 64038 square kilometres. Bihar, Jharkhand, and West Bengal are the states where it flows. The yearly long term analysis of hydrometeorological parameters, including in situ GWL data, were analysed using the M-K test to analyse the upward and downward trend. The results of Bhagirathi 601 (Lower Ganga) shows the significant $\mathrm{P}<0.05$ ) upward trend of precipitation $(\mathrm{Q}=3.51 \mathrm{~mm} /$ year $), \quad$ evapotranspiration $(\mathrm{Q}=2.6 \mathrm{~mm} /$ year $), \quad \operatorname{runoff}(\mathrm{Q}=1.52 \mathrm{~mm} /$ year $)$, temperature $\left(\mathrm{Q}=0.01{ }^{\circ} \mathrm{C} / \mathrm{year}\right)$, whereas water budget shows the insignificant downward trend having sen's slope of $-1.13 \mathrm{BCM} / \mathrm{year}$. The minimum and maximum range of SGWLI for the Bhagirathi sub-basin was observed in the year of 1996 and 2014 respectively, it also acts as the discharge point of the Ganga after flowing to such a long path into the Bay of Bengal (Fig.9).

608 


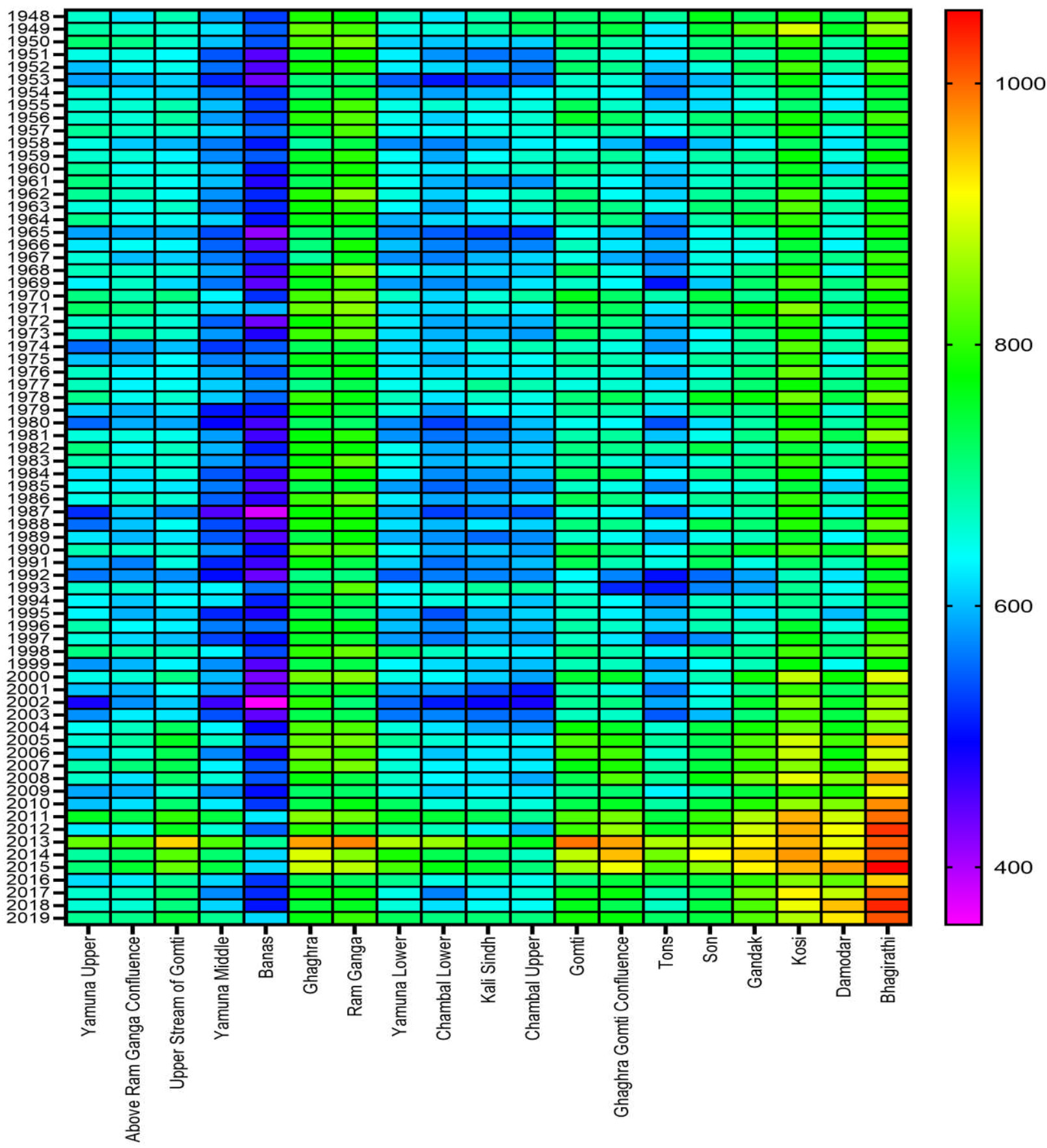

610 Fig.3 Temporal distribution of evapotranspiration from 1948-2019 in sub-basin (mm/year)

611

612

613

614

615

616 


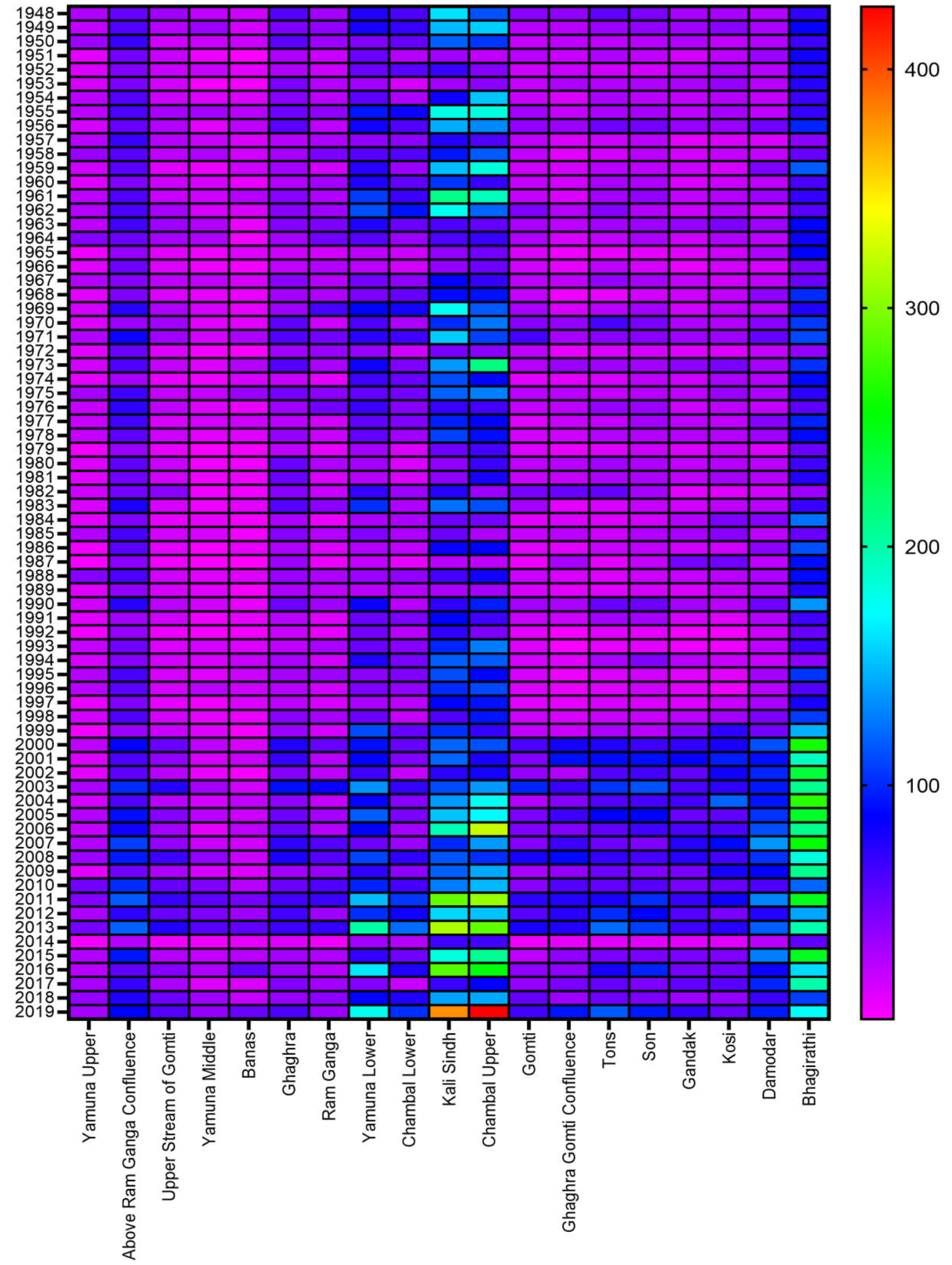

618 Fig.4 Temporal distribution of surface runoff 1948-2019 in sub-basin (mm/year) 


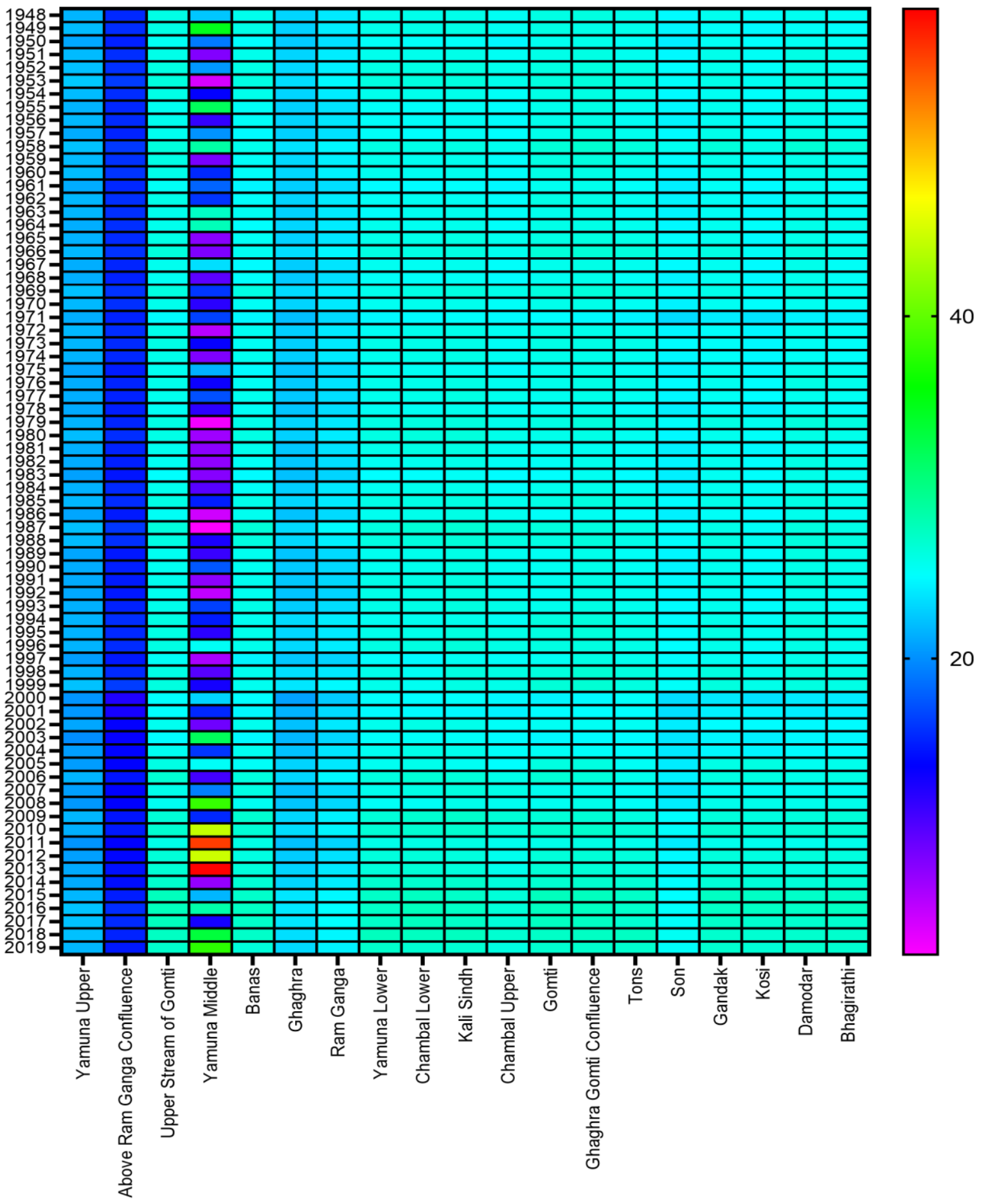

622

623

624

625

626

Fig.5 Temporal distribution of temperature $1948-2019$ in sub-basin $\left({ }^{\circ} \mathrm{C} /\right.$ year $)$ 


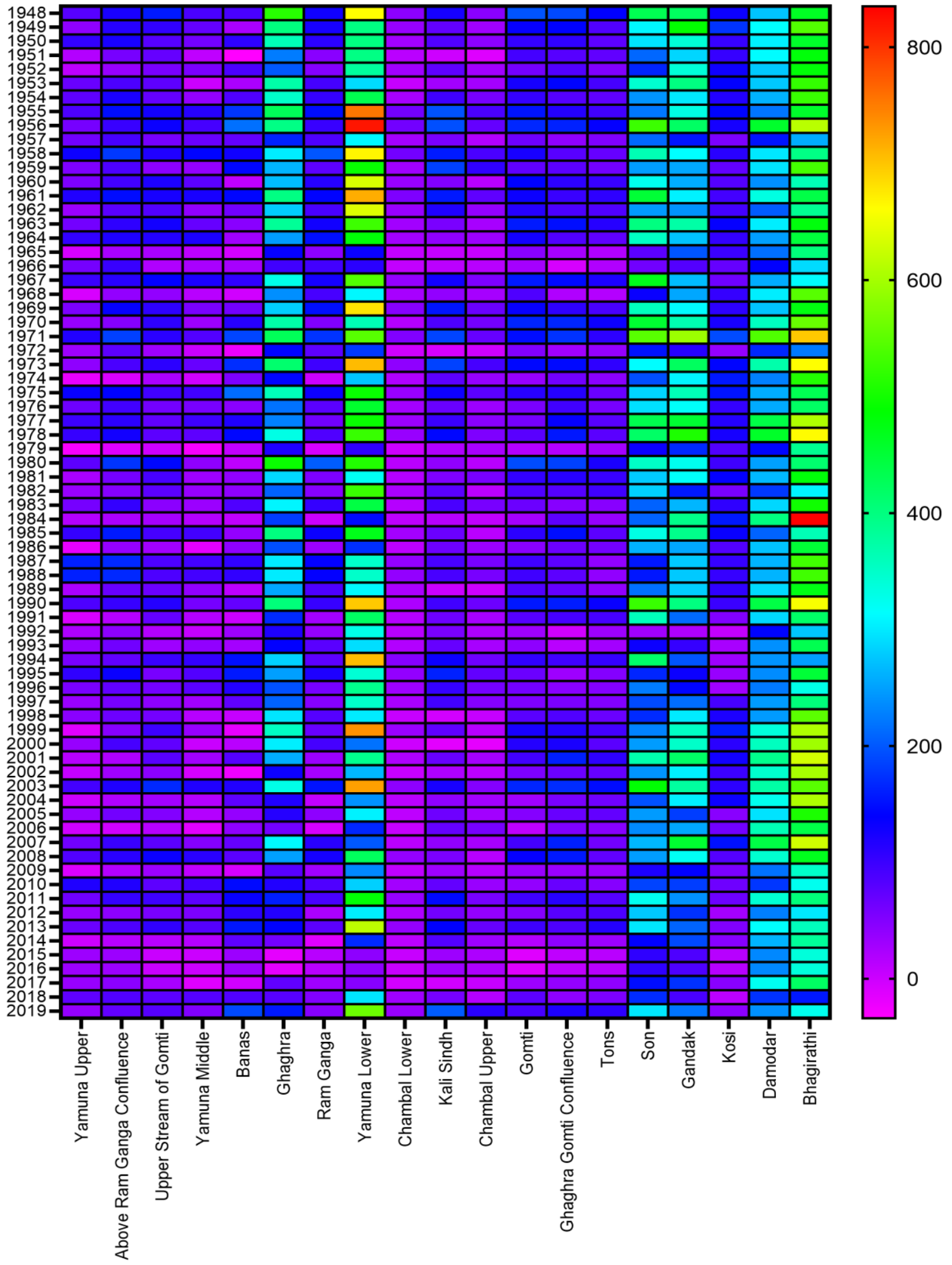




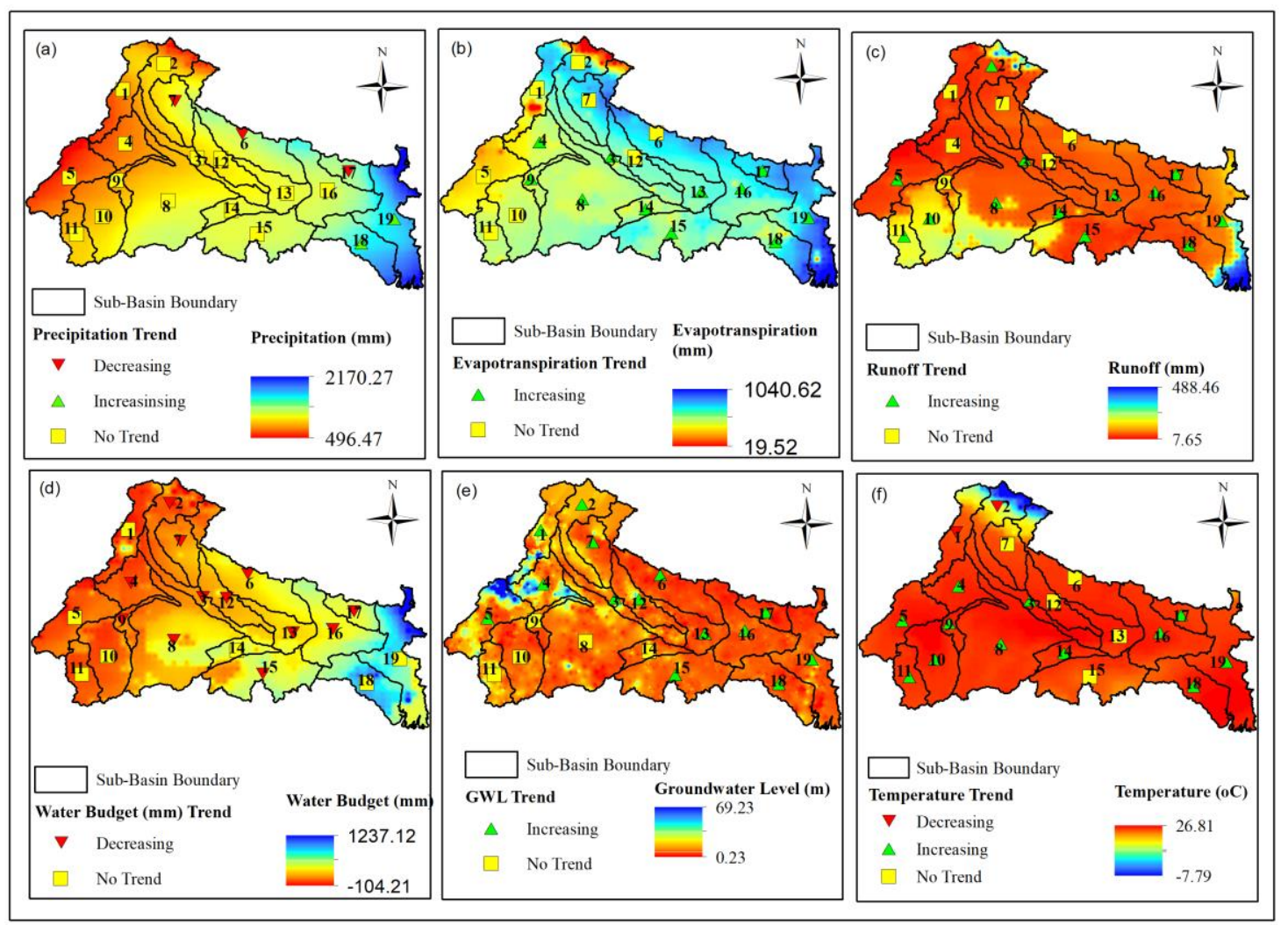

631

632 Fig. 7 Spatial distribution of long term trend and hydrometeorological parameters: (a) 633 precipitation $(\mathrm{mm}),(\mathrm{b})$ evapotranspiration $(\mathrm{mm}),(\mathrm{c})$ runoff $(\mathrm{mm}),(\mathrm{d})$ water budget $(\mathrm{mm}),(\mathrm{e})$ 634 groundwater level (mbgl), and (f) temperature $\left({ }^{\circ} \mathrm{C}\right)$ 


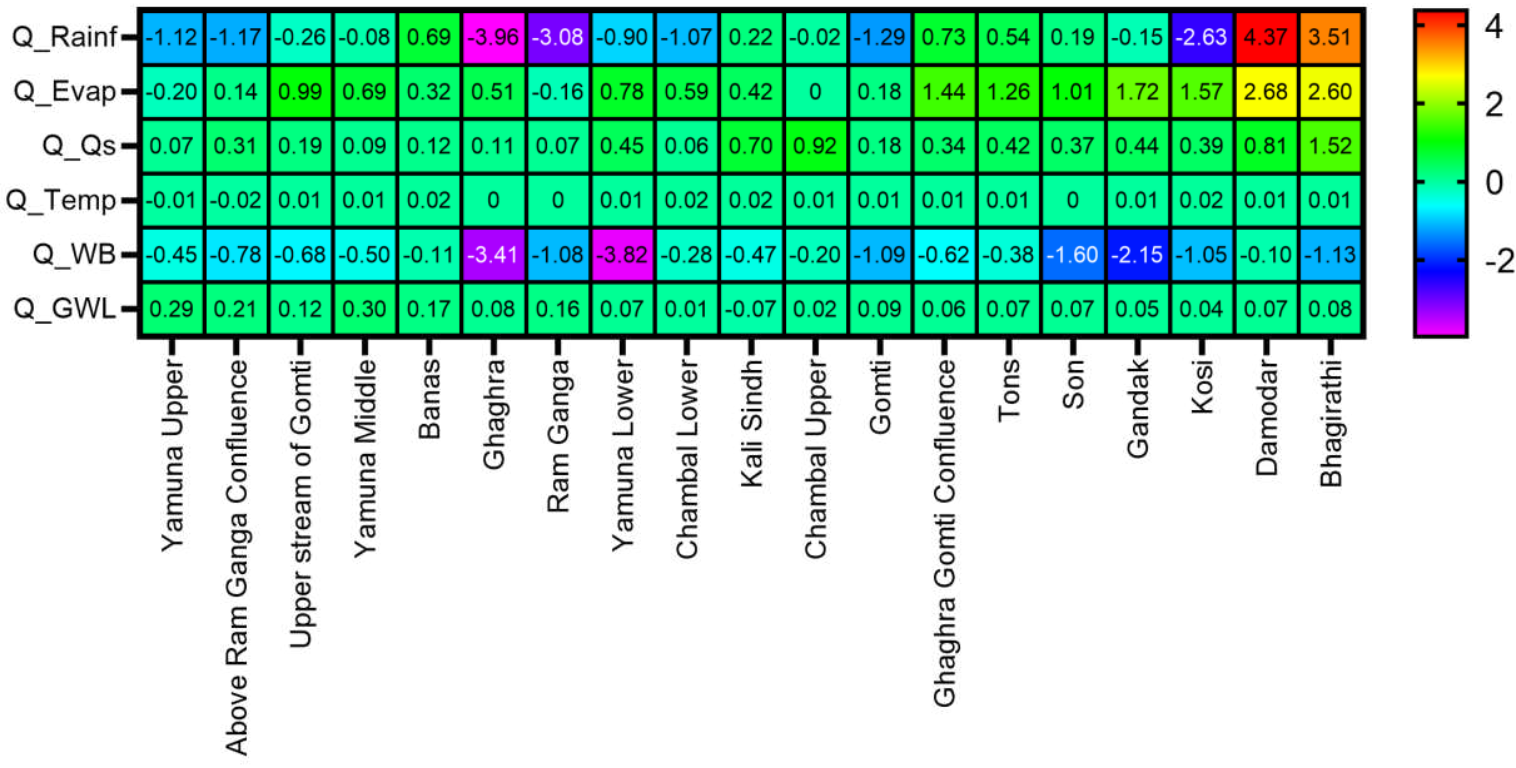

643 Fig.8 Distribution of Sen's slope (Q), for Q_Rainf (mm/yr), Q_Evap (mm/yr), Q_Qs 644 (mm/yr), Q_Temp $\left({ }^{0} \mathrm{C} / \mathrm{yr}\right)$, Q_WB (BCM/yr), and Q_GWL (m/yr) 


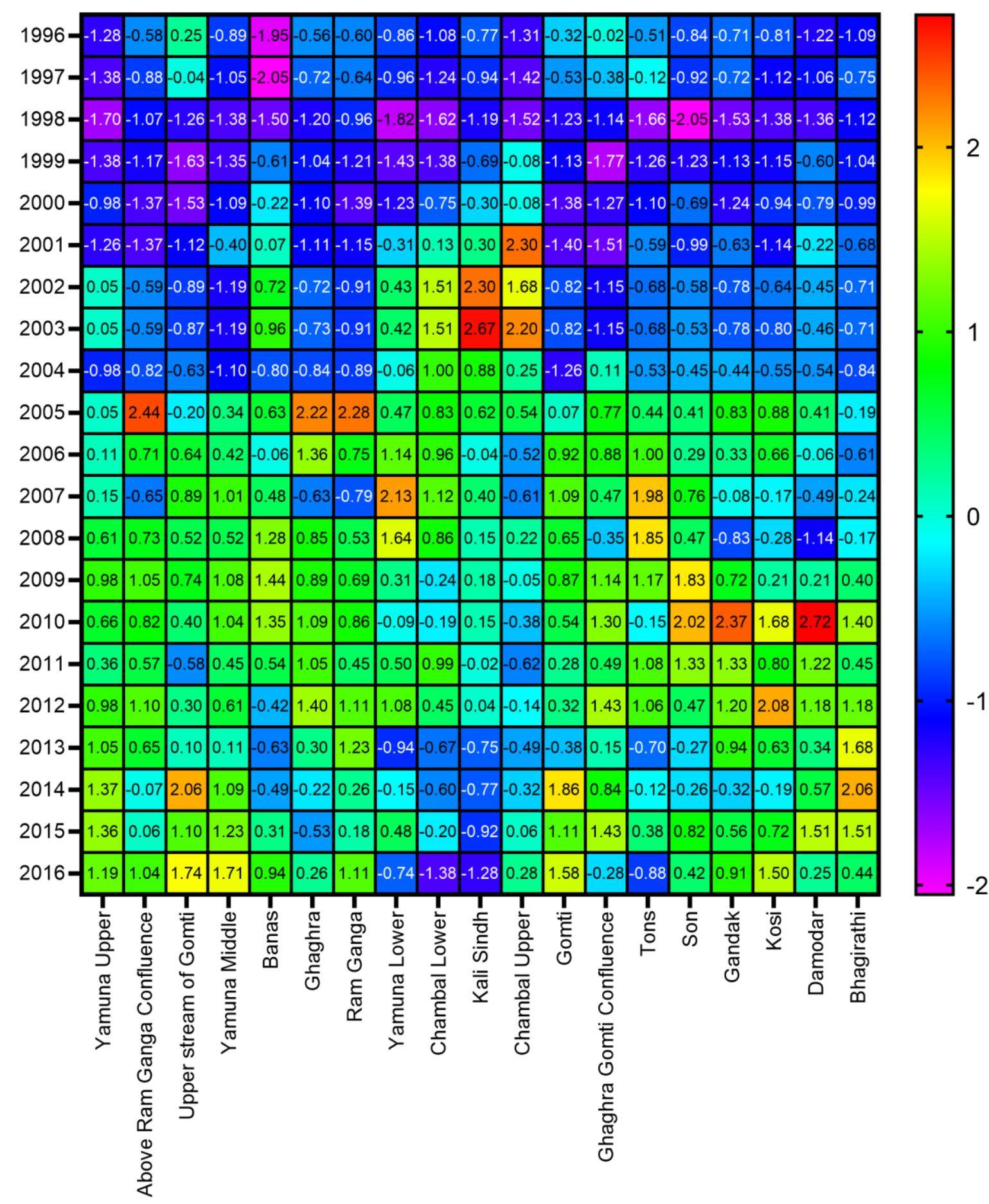

Fig.9 Sub- basin characterisation of Standard Groundwater Level Drought Index (SGWLI)

Table 1 Groundwater drought in the sub-basin of Ganga using in-situ data 


\begin{tabular}{ccccccc}
\hline $\begin{array}{c}\text { Sub-Basin } \\
\text { ID }\end{array}$ & Sub-Basin & $\begin{array}{c}\text { Extreme } \\
\text { Severe } \\
\text { Drought }\end{array}$ & $\begin{array}{c}\text { Severe } \\
\text { Drought }\end{array}$ & $\begin{array}{c}\text { Moderate } \\
\text { Drought }\end{array}$ & $\begin{array}{c}\text { Mild } \\
\text { Drought }\end{array}$ & $\begin{array}{c}\text { No } \\
\text { Drought }\end{array}$ \\
1 & Yamuna Upper & & & 4 & 10 & 7 \\
2 & Above Ram Ganga Confluence & 1 & & 3 & 6 & 11 \\
3 & Upper stream of Gomti & 1 & 1 & 1 & 8 & 10 \\
4 & Yamuna Middle & & 1 & 4 & 6 & 9 \\
5 & Banas & & & 3 & 8 & 10 \\
6 & Ghaghra & 1 & & 4 & 4 & 12 \\
7 & Ram Ganga & 1 & & 3 & 7 & 10 \\
8 & Yamuna Lower & 1 & 1 & 2 & 6 & 11 \\
9 & Chambal Lower & & 2 & 1 & 7 & 11 \\
10 & Kali Sindh & 2 & & & 8 & 11 \\
11 & Chambal Upper & 2 & 1 & & 5 & 13 \\
12 & Gomti & & 2 & 2 & 7 & 10 \\
13 & Ghaghra Gomti Confluence & & & 4 & 7 & 10 \\
14 & Tons & & 2 & 4 & 2 & 13 \\
15 & Son & 1 & 1 & 1 & 7 & 11 \\
16 & Gandak & 1 & & 2 & 6 & 12 \\
17 & Kosi & 1 & 1 & 1 & 6 & 12 \\
18 & Damodar & 1 & 1 & 2 & 5 & 12 \\
19 & Bhagirathi & 1 & 2 & 2 & 3 & 13 \\
\hline
\end{tabular}

653

\section{Conclusion}

In this study, we have evaluated the hydrometeorological parameters for the 19 sub-basin, and

657 have attempted to identify the major parameters influencing groundwater availability in the

658 region. The non-parametric MK-Test along with Sen's slope estimate was done on the 659 hydrometeorological data from the year 1948 to 2019 for 72 years. The hydrometeorological 660 analysis of water budget including in-situ based monitoring well used to determine 661 thegroundwater drought, shows the groundwater stress. Most of the results shows the statistical 662 significant declining trend of water budget. It is also observed that the hydrometeorological 663 extremes also increases leading to groundwater drought.Water storage and groundwater flow 664 analyses in regional studies are guided by hydrometeorology, topography, land use pattern, and 665 morphometry. 
666 In India's water sector, inequitable water access, poor water quality, unsustainable use of 667 groundwater, particularly in agriculture, and weak governance are some of the major concerns 668 (http://ioraecological.com). The National Water Policy (NWP,2012) emphasised water 669 allocation's ecological and environmental implications. There was a focus on using 670 hydrological units and taking into account quality, quantity, and environmental factors when 671 making water resource decisions. According to the 2016 draught of the National Water 672 Framework (NWF) Bill, which embodies the principles of water protection, conservation, 673 regulation, as well as management, legal and executive action on water is permitted at all levels

674 of government.

675 Conflict of interest:

676 The authors declare, they have no conflict of interest.

677 Funding Statement:

678 No external funding received.

Author's Contribution:

680

Mohd Sayeed Ul Hasan: Conceptualization; Methodology; Software; Formal analysis; Investigation;

681 Visualization; Writing - original draft

682 Abhishek Kumar Rai: Supervision; Conceptualization; Project administration; Resources; Writing - Review \& 683 Editing

684 Availability of data and material:

685 The data used in this manuscript are available on their respective website and free available.

686 Code Availability: No code applicable.

687 Ethics Approval: We confirm that this work is original and has not been published elsewhere, nor is it currently 688 under consideration for publication elsewhere. manuscript.

691 
The authors thank the Central Ground Water Board (CGWB), and Giovanni

(https://giovanni.gsfc.nasa.gov/giovanni/), for providing the relevant data. We are also thankful to the Indian Institute of Technology Kharagpur and Aliah University for providing assistance with all the relevant work environments and infrastructure facilities. This work is part of the $\mathrm{PhD}$ thesis of the first author, and also thankful to the anonymous reviewer for giving valuable comments and suggestions to enhance the overall quality of the manuscript.

\section{References}

Acreman, M., Smith, A., Charters, L., Tickner, D., Opperman, J., Acreman, S., Edwards, F., \& Sayers, P. (2021). Evidence for the effectiveness of nature-based solutions to water issues in Africa OPEN ACCESS Evidence for the effectiveness of nature-based solutions to water issues in Africa.

Bhuiyan, C., 2000. Various Drought Indices For Monitoring Drought Condition In Aravalli Terrain Of India.

Birylo, M., 2017. Uncertainty in estimated water cycle determined with atmospheric budget, water budget and total water storage 177-184.

Birylo, M., Rzepecka, Z., Kuczynska-Siehien, J., Nastula, J., 2018. Analysis of water budget prediction accuracy using ARIMA models. Water Sci. Technol. Water Supply 18, 819830. https://doi.org/10.2166/ws.2017.156

Birylo, Monika, Rzepecka, Z., Nastula, J., 2018. Assessment of the Water Budget from GLDAS Model. Proc. - 2018 Balt. Geod. Congr. BGC-Geomatics 2018 86-90. https://doi.org/10.1109/BGC-Geomatics.2018.00022

Bisht, D.S., Chatterjee, C., Raghuwanshi, N.S., Sridhar, V., 2018. Spatio-temporal trends of rainfall across Indian river basins. Theor. Appl. Climatol. 132, 419-436. https://doi.org/10.1007/s00704-017-2095-8

Bloomfield, J.P., Marchant, B.P., 2013. Analysis of groundwater drought building on the standardised precipitation index approach. Hydrol. Earth Syst. Sci. 17, 4769-4787. https://doi.org/10.5194/hess-17-4769-2013

Bring, A., Shiklomanov, A., Lammers, R.B., 2017. Pan-Arctic river discharge: Prioritizing monitoring of future. Earth's Futur. 5, 72-92. https://doi.org/10.1002/eft2.175

CGWB, 2012. Manual on Aquifer Mapping, Government of India, Ministry of Water Resources. Gov. India, Minist. Water Resour. Gr. Water Board 72.

da Silva, R.M., Santos, C.A.G., Moreira, M., Corte-Real, J., Silva, V.C.L., Medeiros, I.C., 2015. Rainfall and river flow trends using Mann-Kendall and Sen's slope estimator statistical tests in the Cobres River basin. Nat. Hazards 77, 1205-1221. https://doi.org/10.1007/s11069-015-1644-7

Dinpashoh, Y., Jhajharia, D., Fakheri-Fard, A., Singh, V.P., Kahya, E., 2011. Trends in reference crop evapotranspiration over Iran. J. Hydrol. 399, 422-433. https://doi.org/10.1016/j.jhydrol.2011.01.021

Duan, Z., Bastiaanssen, W.G.M., 2013. Estimating water volume variations in lakes and 
reservoirs from four operational satellite altimetry databases and satellite imagery data. Remote Sens. Environ. 134, 403-416. https://doi.org/10.1016/j.rse.2013.03.010

Fang, H., Hrubiak, P.L., Kato, H., Rodell, M., Teng, W.L., Vollmer, B.E., 2008. Global land data assimilation system (GLDAS) products from nasa hydrology data and information services center (HDISC). Am. Soc. Photogramm. Remote Sens. - ASPRS Annu. Conf. 2008 - Bridg. Horizons New Front. Geospatial Collab. 1, 183-190.

Halder, S., Roy, M.B., Roy, P.K., 2020. Analysis of groundwater level trend and groundwater drought using Standard Groundwater Level Index : a case study of an eastern river basin of West Analysis of groundwater level trend and groundwater drought using Standard Groundwater Level Index : a case 1-2. https://doi.org/10.1007/s42452-020-2302-6

Hall, A.C., Schumann, G.J.P., Bamber, J.L., Bates, P.D., 2011. Tracking water level changes of the Amazon Basin with space-borne remote sensing and integration with large scale hydrodynamic modelling: A review. Phys. Chem. Earth 36, 223-231. https://doi.org/10.1016/j.pce.2010.12.010

Hasan, M.S.U., Rai, A.K., 2020. Groundwater quality assessment in the Lower Ganga Basin using entropy information theory and GIS. J. Clean. Prod. 274, 123077. https://doi.org/10.1016/j.jclepro.2020.123077

Healy, R.W., Winter, T.C., LaBaugh, J.W., Franke, O.L., 2007. Water budgets: Foundations for effective water- resources and environmental management: U.S. Geological Survey Circular 1308, 90 p. Ars Comb. 95, 65-70. https://doi.org/10.1016/j.cell.2008.09.034

Jarraud, M., Steiner, A., 2012. Summary for policymakers, Managing the Risks of Extreme Events and Disasters to Advance Climate Change Adaptation: Special Report of the Intergovernmental Panel on Climate Change. https://doi.org/10.1017/CBO9781139177245.003

Lv, Meixia, Ma, Z., Yuan, X., Lv, Meizhao, Li, M., Zheng, Z., 2017. Water budget closure based on GRACE measurements and reconstructed evapotranspiration using GLDAS and water use data for two large densely-populated mid-latitude basins. J. Hydrol. 547, 585-599. https://doi.org/10.1016/j.jhydrol.2017.02.027

Kendall M. G., (1975) Rank Correlation Methods. London, Charles Griffi

Kisi O, Ay M (2014) Comparison of Mann-Kendall and innovative trend method for water quality pa- rameters of the Kizilirmak River, Turkey. J Hydrol 513(26):362-375. doi:10.1016/j.jhydrol.2014.03. 005

Mann H. B., (1945) Nonparametric tests against trend. Econometrica 13: 245-59

Maliva, R., Missimer, T., 2012. Water budget, Environmental Science and Engineering (Subseries: Environmental Science). https://doi.org/10.1007/978-3-642-29104-3_6

Marques, R., Santos, C.A.G., Moreira, M., Valeriano, C., Isabella, C.L.S., 2015. Rainfall and river flow trends using Mann - Kendall and Sen 's slope estimator statistical tests in the Cobres River basin. https://doi.org/10.1007/s11069-015-1644-7

Mohsin, T., Gough, W.A., 2010. Trend analysis of long-term temperature time series in the Greater Toronto Area (GTA). Theor. Appl. Climatol. 101, 311-327. https://doi.org/10.1007/s00704-009-0214-X

Neeti, N., Eastman, J.R., 2011. A Contextual Mann-Kendall Approach for the Assessment of Trend Significance in 15, 599-611. https://doi.org/10.1111/j.1467-9671.2011.01280.x

Panda, A., Sahu, N., 2019. Trend analysis of seasonal rainfall and temperature pattern in Kalahandi, Bolangir and Koraput districts of Odisha, India. Atmos. Sci. Lett. 20, 1-10. https://doi.org/10.1002/as1.932

Prakash Kushwaha, A., Deep Tiwari, A., Dangar, S., Shah, H., Shwarup Mahto, S., Mishra, V., 2021. Multimodel assessment of water budget in Indian sub-continental river basins. J. Hydrol. 603, 126977. https://doi.org/10.1016/j.jhydrol.2021.126977 
Qin, J., Hao, Z.C., Wang, L., Jiang, W.J., Lu, C.Y., 2011. Evaluation of IPCC AR4 global climate model simulation over the Yangtze River Basin. IAHS-AISH Publ. 346, 144 149.

Roads, J., Lawford, R., Bainto, E., Berbery, E., Chen, S., Fekete, B., Gallo, K., Grundstein, A., Higgins, W., Kanamitsu, M., Krajewski, W., Lakshmi, V., Leathers, D., Lettenmaier, D., Luo, L., Maurer, E., Meyers, T., Miller, D., Mitchell, K., Mote, T., Pinker, R., Reichler, T., Robinson, D., Robock, A., Smith, J., Srinivasan, G., Verdin, K., Vinnikov, K., Vonder Haar, T., Vörösmarty, C., Williams, S., Yarosh, E., 2003. GCIP water and energy budget synthesis (WEBS). J. Geophys. Res. D Atmos. 108. https://doi.org/10.1029/2002jd002583

Rodell, M., Velicogna, I., Famiglietti, J.S., 2009. Satellite-based estimates of groundwater depletion in India. Nature 460, 999-1002. https://doi.org/10.1038/nature08238

Seneviratne, S.I., Viterbo, P., Lüthi, D., Schär, C., 2004. Inferring changes in terrestrial water storage using ERA-40 reanalysis data: The Mississippi River basin. J. Clim. 17, 20392057. https://doi.org/10.1175/1520-0442(2004)017<2039:ICITWS>2.0.CO;2

Shahid, S., Kumar, M., 2010. Groundwater Drought in the Northwestern Districts of Bangladesh 1989-2006. https://doi.org/10.1007/s11269-009-9534-y

Singh, A., Seitz, F., Eicker, A., Güntner, A., 2016. Water budget analysis within the surrounding of prominent lakes and reservoirs from multi-sensor earth observation data and hydrological models: Case studies of the Aral Sea and Lake Mead. Remote Sens. 8. https://doi.org/10.3390/rs8110953

Spennemann, P.C., Rivera, J.A., Celeste Saulo, A., Penalba, O.C., Rui, H., Beaudoing, H.K., 2015. README Document for GLDAS Version 2 Data Products. Goddard Earth Sci. Data Inf. Serv. Cent. (GES DISC) 16, 1-32. https://doi.org/http://hydro1.sci.gsfc.nasa.gov/ data/s4pa/GLDAS/GLDAS_NOAH10_M.2.0/doc/README_GLDAS2.pdf

Swenson, S., Wahr, J., 2002. Methods for inferring regional surface-mass anomalies from Gravity Recovery and Climate Experiment (GRACE) measurements of time-variable gravity. J. Geophys. Res. Solid Earth 107, ETG 3-1-ETG 3-13. https://doi.org/10.1029/2001jb000576

Zhang, J., Xu, K., Yang, Y., Qi, L., Hayashi, S., Watanabe, M., 2006. Measuring water storage fluctuations in Lake Dongting, China, by Topex/Poseidon satellite altimetry. Environ. Monit. Assess. 115, 23-37. https://doi.org/10.1007/s10661-006-5233-9

Yue S and Wang C Y 2002 Regional stream flow trend detection with consideration of both temporal and spatial autocorrelation. International Journal of Climatology 22: 923-46 